\title{
Adaptability and Stability of Corn Hybrids in Southern Brazilian Environments
}

\author{
Carlos Busanello르, Velci Queiróz de Souza ${ }^{1}$, Antonio Costa de Oliveira ${ }^{2}$, Maicon Nardino ${ }^{1}$, Diego Beretta ${ }^{2}$, Braulio \\ Otomar Caron ${ }^{1}$, Denise Schmidt ${ }^{1}$, Victoria Freitas de Oliveira ${ }^{2} \&$ Valmor Antonio Konflaz ${ }^{3}$ \\ ${ }^{1}$ Department of Plant Science and Environmental, University Federal of Santa Maria campus Frederico \\ Westphalen, Frederico Westphalen, RS, Brazil \\ ${ }^{2}$ Department of Plant Science, University Federal of Pelotas campus Capão do Leão, Pelotas, RS, Brazil \\ ${ }^{3}$ Pato Branco, KSP Seed and Research, PR, Brazil
}

Correspondence: Antonio Costa de Oliveira, Department of Plant Science, Plant Genomics and Breeding Center, University Federal of Pelotas, Campus Capão do Leão, C.P. 354, 96010-900, Pelotas, RS, Brazil. E-mail: acostol@cgfufpel.org

Received: April 16, 2015 Accepted: July 12, 2015 Online Published: August 15, 2015

doi:10.5539/jas.v7n9p228 URL: http://dx.doi.org/10.5539/jas.v7n9p228

\begin{abstract}
The objective of this study was to identify, among the 27 hybrids evaluated, the best adaptability and stability responses for corn grain yield in five environments. The experiments were conducted in the 2009/2010 crop seasons in a randomized complete block design with three replications. There was significant $\mathrm{G} \times \mathrm{E}$ interaction effects $(\mathrm{p} \leq 0.05)$ only for the yield and cob mass characters. Among the hybrids tested, 14 of them were ranked as responsive to environmental improvement for grain yield. The other genotypes have good performance in harsh environments. For the stability analysis, significance was found for the hybrids 5, 7 and 27. For cob mass, all hybrids showed significant adaptability, for stability, only genotypes 20 and 24 expressed significance.
\end{abstract}

Keywords: biometric models, cob mass, yield

\section{Introduction}

The crossing of inbred lines from different heterotic groups can lead to the production of high yielding hybrids. In the last few years in Brazil, hybrid seeds have reached 70\% market share of the cultivated area (Paulista Association of Seeds and Seedlings Producers [APPS], 2009), and the trend shows a steady growth.

Hybrid combinations between lines with high combining ability, as well as their "per se" potential is one of the basic objectives in a hybrid breeding program (Allard, 1971). The performance of corn genotypes with good agronomic traits is the result of an heterotic effect, which is obtained by crossing lines with good general and specific combining abilities (Hallauer, Carena, \& Miranda Filho, 2010).

The phenotypic expression is given by the sum of hybrid genotype and environment effects plus the genotype $\mathrm{x}$ environment ( $\mathrm{G} \times \mathrm{E}$ ) interaction. The environment and interaction provide different phenotype performances, even for hybrids resulting from the cross of inbred lines. The phenotypic expression is altered in different environments for traits with low penetrance and expressivity (Ramalho et al., 2012).

The large territory of Brazil implicates in a range of environmental variations, causing difficulties for breeders, since the identification of genotypes with broad adaptation becomes a hard task. Genotypic values are measured regarding to a particular group of environments that occur within a year period in a number of homogeneous locations in a given geographical area (Allard, 1971).

The understanding of genotype adaptability to specific environments is important for plant breeders because it helps to identify genotypes responsive to favorable environments. The stability refers to the genotype ability to give permanent predictable responses to environmental stimuli, whereas in a number of different environments, stability is important for the evaluation of genotype potential, allowing the identification of genotypes that have minimal interaction with the environment (Murakami, Cardoso, Cruz, \& Bizão, 2004).

The use of biometric templates came to support the work of breeders against variations generated by the effect of $\mathrm{Gx}$ E interactions, as well as to identify hybrids with desired adaptability and stability. 
There are few studies on how adapted tropical corn germplasm affects the development of superior hybrids. Especially in Brazil, such studies are of fundamental importance for the increase in the development of hybrid competitiveness (Aguiar, Schuster, Amaral Júnior, Scapim, \& Vieira, 2008).

In recent years, various approaches have been proposed focusing in an easy and accurate way to measure genotype performance in various environments (Balestre, Von Pinho, Souza, \& Oliveira, 2009). Therefore, numerous scientific studies that identify corn hybrid performances in different environments have been published (Badu-Apraku, Oyekunle, Akinwale, \& Aderounmu, 2013; Badu-Apraku et al., 2013; Beiragi, Khorasani, \& Nabavi, 2011; Liu et al., 2013; Niu et al., 2013; Pena et al., 2012). These analyses help to identify genotypes responsive to favorable environments and also to identify unresponsive hybrids, thus allowing to generate investment planning regarding hybrids that have higher genetic potential.

Although the yield measured is a combined result of genotype, environment, and their interaction effects, $G$ and GxE are only relevant for cultivar assessment and environment characterization (Yan, Hunt, Sheng, \& Szlavnics, 2000). The aim of this study was to evaluate hybrid adaptability and stability in five contrasting environments, and use the interaction effects to point out independent characters in these conditions.

\section{Material and Methods}

This work was conducted in the crop season of 2009/2010 in five different environments located in the three southern Brazilian states. In Rio Grande do Sul State, the test was conducted in Frederico Westphalen County, located at $27^{\circ} 23^{\prime} 47.80^{\prime \prime}$ South latitude and $53^{\circ} 25^{\prime} 35.26^{\prime \prime}$ West longitude, with 480 meters of altitude in the trial site. In Santa Catarina State, the test was conducted in the Guaraciaba County, at $26^{\circ} 35^{\prime} 44.76^{\prime \prime}$ South latitude and $53^{\circ} 32^{\prime} 06.92^{\prime \prime}$ West longitude, $650 \mathrm{~m}$ altitude in the trial site. In Paraná, the tests were conducted in the following sites: Palmas County, located at 26 $24^{\prime} 49.15^{\prime \prime}$ South latitude and 51 ${ }^{\circ} 53^{\prime} 54.96^{\prime \prime}$ West longitude with 1090 meters of

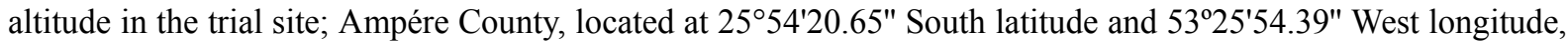
with 580 meters of altitude in the trial site and Clevelândia County, located at $26^{\circ} 21^{\prime} 17.52^{\prime \prime}$ South latitude and $52^{\circ} 28^{\prime} 56.22 "$ West longitude to 860 meters of altitude in the trial site.

For the adaptability and stability analyses, 27 corn hybrids were tested in a randomized complete block design with three replications per location was used. Soil tillage, sowing and cultivation were the same for the five sites, according to the phenological stages and the crop needs. The crop was harvested at $20 \%$ moisture content for all sites, being the data corrected to $13 \%$ moisture to standardize the information.

The variables analyzed in the five environments were: grain yield $\left(\mathrm{kg} \mathrm{ha}^{-1}\right)$, ear diameter $(\mathrm{mm})$, ear length $(\mathrm{cm})$, number of rows, number of kernels per row (performed by manual counting three ears), total ear weight (g), grain weight ear ${ }^{-1}(\mathrm{~g})$, cob diameter $(\mathrm{mm})$ cob mass $(\mathrm{g})$, thousand grain weight $(\mathrm{g})$, respectively measured by manual counting three replicates of 100 seeds and adjusted to thousand number of grains per ear ${ }^{-1}$.

Data were subjected to variance analysis to identify the G x E interaction. Noting the significant interaction, we proceeded to regression analysis of adaptability and stability according to the Eberhart and Russel (1966) model:

$$
Y_{i j}=\beta_{o i}+\beta_{l i} I_{j}+\delta_{i j}+\bar{\varepsilon}_{i j}
$$

Where,

$\beta_{o i}$ : overall average of genotype $\mathrm{i}$;

$\beta_{l i}$ : linear response of genotype i environmental variation;

$I_{j}$ : environmental index $(\mathrm{j}=1,2, \ldots \mathrm{a})$, being $I_{j}=\frac{Y_{j}}{g}-\frac{Y}{g e}$;

$\delta_{i j}:$ deviation regression;

$\bar{\varepsilon}_{i j}$ : experimental error average.

Data analyses were performed using the Genes Software, version 2009.0.7 (Cruz, 2013).

\section{Results and Discussion}

The variance analysis revealed non-significant effects for $\mathrm{G} \times \mathrm{E}$ interaction for ear diameter, ear length, number of rows, number of kernels per row, total ear mass, grain weight per ear, cob diameter, weight of a thousand grains and number of grains per ear. Therefore, for these variables, adaptability and stability analyses were not performed. The characters grain yield and cob mass expressed significant effects for $\mathrm{G} x \mathrm{E}$ interaction (Table 1). Most quantitative traits such as yield, are polygenic in nature and very influenced by the environment. The G x E interaction strongly influences the expression of these quantitative traits (Schmildt et al., 2011). 
Table 1. Summary of the variance analysis to yield in $\mathrm{kg}^{-1}$ and cob mass in grams, twenty seven corn hybrids in five local in Southern Brazil, Frederico Westphalen/RS, 2013.

\begin{tabular}{lll}
\hline \multirow{2}{*}{ FV } & \multicolumn{2}{c}{ QM } \\
\cline { 2 - 3 } & Yield & Cob mass \\
\hline Environment & 6396597,777 & 4147,682 \\
Genotype & 7529127,898 & 766,648 \\
Int. G x E & $1566517,715^{*}$ & $95,817^{*}$ \\
Residue & 910216,393 & 73,623 \\
\hline Average & 8952,21 & 32,21 \\
C.V. $(\%)$ & 11 & 27 \\
\hline
\end{tabular}

Note. * Significant by the F test $(\mathrm{p} \leq 0.05)$.

The interaction between the $\mathrm{G} \times \mathrm{E}$ factors indicates that the effects of all variations are not explained individually for grain yield and cob mass. Furthermore, the effect provided by the environment condition promotes differences in expression of these traits.

The average grain yield of hybrids (Table 2) in five environments indicated that genotypes 1, 2, 4, 5, 7, 12, 13, 14,16 and 27 were not different, but were superior to $3,6,8,9,10,11,15,17,18,19,20,21,22,23,24,25$ and 26 by grouping the Scott and Knott $(1974)$ model averages $(p \leq 0.05)$. If the goals of the breeding program were hybrid development or selection among the genotypes with higher performance, the first would possibly be selected for these specific environmental conditions. However, the possibility that in more specific conditions, such as an intrinsic case of an environment, some hybrids lower than the average evaluation would have superiority can not be ruled out. These facts would be linked to the better use of environmental stimuli by hybrids. Corn improvement requires high costs to obtain an hybrid, therefore it is important to evaluate the genotype scope on the market and its economic viability. High adaptability and stability hybrids have better agronomic performance and commercial viability.

Regarding cob mass, no significant effect for any hybrid compared to the average performance of the variable in the five environmental conditions was observed.

Through the adaptability analysis of Eberhart and Russell (1966), the hybrids 1, 3, 4, 5, 6, 7, 8, 9, 10, 11, 14, 20, 22 and 24 showed significant effects with $\beta>1$. These hybrids are scored as responsive to favorable environments. The yield magnitude of these hybrids is influenced positively by the ability to take advantage of predictable stimuli of environments.

Hybrids unresponsive to the improvement of environmental conditions, being more adaptable to harsh environments have $\beta<1$, which can be observed for the genotypes $12,13,15,16,17,18,19,21,23,25,26$ and 27.

An analysis of variance for deviations in the linear regression $\left(\mathrm{S}^{2} \mathrm{~d}\right)$ was performed to measure the stability of genotypes. The great majority of genotypes $(1,2,3,4,6,8,9,10,11,12,13,14,15,16,17,18,19,20,21,22$, 23, 24, 25 and 26) revealed predictable stability performance in the environments regarding yield. However, the hybrids 5,7 and 27 presented significant $(\mathrm{p} \leq 0.01)$ deviations, indicating that the hybrids do not have a predictable response to environmental fluctuations. These genotypes did not respond to possible environmental changes in a predictable manner, which prevents them from taking advantage of these stimuli in a linear fashion, in other words, can respond or not to the new environment.

The determination coefficients $\left(\mathrm{R}^{2}\right)$ for grain yield $\left(\mathrm{kg} \mathrm{ha}^{-1}\right)$ were high (above $80 \%$ ) for the genotypes $2,3,4,11$, 14, 16 and 24. A $\mathrm{R}^{2}$ value higher than the above would mean that these hybrids have good stability for grain yield. Genotypes showing a $\mathrm{R}^{2}$ above $80 \%$ maintain their predictability, indicating small deviations from the linear response (Cruz, Torres, \& Vencovsky, 1989).

The environmental indices estimated for grain yield are shown in Figure 1. The variation in the yield of corn genotypes indicates a instability of soil and climatic conditions in the different studied environments.

Grain yield is one of the most sought traits by breeding programs. In general, one applies selection for traits indirectly related to yield and, towards the end of the program, a higher selection index is applied to increase effectiveness in obtaining high yielding genotypes. The yield expression is controlled by quantitative or polygenic traits, i.e., it depends on the action of many genes. When the selective pressure is high at the beginning 
of the breeding program, a few heterozygous inbred lines can be eliminated, affecting the number of superior lines reaching final trials.

For cob mass, all genotypes showed significant and positive effects for adaptability and stability. However, the hybrids $2,3,13,18,19,20,21,22,23,24,25$ and 27 showed (Table 2) adaptability to climatic conditions in the five locations evaluated. These hybrids require favorable conditions, since they respond positively to improvements in environmental conditions. The hybrids $1,4,5,6,7,8,9,10,11,12,14,15,16,17$ and 26 showed better adaptability to unfavorable environments.

For stability, significant effects were detected only for hybrids 20 and 24, being all the other hybrids unstable when comparing the five environments. Differences between genotypes with the same level of heterozygosis and heterogeneity may occur regarding the expressiveness of homeostatic functions (Naspolini, 1975). The increased homeostasis degree of a genotype increases its ability to acclimate to one environment. According to the author, this ability is transferred through paternal lineages of hybrids. Although homeostasis is a desirable feature, it has no value if it is not associated with yield components. Soon the hybrid is not acceptable independent of it stability performance (Borém \& Miranda, 2009). 
Table 2. Adaptability and stability parameters estimated using Eberhart and Russell (1966) and cluster averages with Scott and Knott (1974), for the grain yield characteristics $\left(\mathrm{kg} \mathrm{ha}^{-1}\right)$ and adaptability and stability for cob mass in grams for twenty seven corn hybrids, in five local in Southern Brazil, Frederico Westphalen/RS, 2013

\begin{tabular}{|c|c|c|c|c|c|c|c|c|}
\hline \multirow{2}{*}{ Gen } & \multicolumn{4}{|c|}{ Yield } & \multicolumn{4}{|c|}{ Cob mass } \\
\hline & Average $^{1}$ & $\beta 1$ & $\mathrm{~S}^{2} \mathrm{~d}$ & $\mathrm{R}^{2}(\%)$ & Average & $\beta 1$ & $\mathrm{~S}^{2} \mathrm{~d}$ & $\mathrm{R}^{2}(\%)$ \\
\hline 1 & $9036.10 \mathrm{a}$ & $1,17^{*}$ & $302184,88^{\mathrm{ns}}$ & 19 & 37,26 & $0,84^{*}$ & $-10,78^{\mathrm{ns}}$ & 78 \\
\hline 2 & $9311,45 \mathrm{a}$ & $0,73^{*}$ & $-299767,88^{\mathrm{ns}}$ & 94 & 46,07 & $1,46^{*}$ & $4,85^{\mathrm{ns}}$ & 83 \\
\hline 3 & $9102,65 b$ & $1,80^{*}$ & $-234746,39^{\mathrm{ns}}$ & 83 & 39,11 & $1,10^{*}$ & $-20,20^{\mathrm{ns}}$ & 95 \\
\hline 4 & $9545,22 \mathrm{a}$ & $2,07 *$ & $-279560,51^{\mathrm{ns}}$ & 95 & 37,20 & $0,88^{*}$ & $-12,31^{\mathrm{ns}}$ & 81 \\
\hline 5 & $9106,88 \mathrm{a}$ & $2,88^{*}$ & $4587588,31^{* *}$ & 15 & 34,38 & $0,89 *$ & $-2,21^{\mathrm{ns}}$ & 71 \\
\hline 6 & $8337,69 b$ & $2,85^{*}$ & $242784,32^{\mathrm{ns}}$ & 61 & 32,26 & $0,85^{*}$ & $-14,79^{\mathrm{ns}}$ & 84 \\
\hline 7 & $9312,28 \mathrm{a}$ & $1,47^{*}$ & $1273296,96^{* *}$ & 13 & 23,08 & $0,47^{*}$ & $-19,20^{\mathrm{ns}}$ & 74 \\
\hline 8 & $8594,77 b$ & $1,36^{*}$ & $-154776,89^{\mathrm{ns}}$ & 57 & 33,87 & $0,51^{*}$ & $-12,41^{\mathrm{ns}}$ & 59 \\
\hline 9 & $8669,18 b$ & $1,40^{*}$ & $-142029,13^{\mathrm{ns}}$ & 56 & 28,77 & $0,43 *$ & $-23,02^{\mathrm{ns}}$ & 89 \\
\hline 10 & $7314,78 b$ & $1,43^{*}$ & $36623,11^{\mathrm{ns}}$ & 39 & 26,20 & $0,36^{*}$ & $-22,57^{\mathrm{ns}}$ & 82 \\
\hline 11 & $8419,52 b$ & $1,68^{*}$ & $-205372,89^{\mathrm{ns}}$ & 75 & 28,31 & $0,47 *$ & $-21,47^{\mathrm{ns}}$ & 83 \\
\hline 12 & $9728,98 \mathrm{a}$ & $0,73^{*}$ & $441197,85^{\mathrm{ns}}$ & 7 & 26,20 & $0,63 *$ & $-20,84^{\mathrm{ns}}$ & 88 \\
\hline 13 & $10340,11 \mathrm{a}$ & $-0,10^{*}$ & $-68323,36^{\mathrm{ns}}$ & 1 & 34,02 & $1,48^{*}$ & $4,69^{\mathrm{ns}}$ & 84 \\
\hline 14 & $9656,50 \mathrm{a}$ & $2,40^{*}$ & $-291597,94^{\mathrm{ns}}$ & 98 & 24,98 & $0,39 *$ & $-16,08^{\mathrm{ns}}$ & 55 \\
\hline 15 & $9031,02 b$ & $-0,61^{*}$ & $-48632,01^{\mathrm{ns}}$ & 13 & 20,24 & $0,69 *$ & $-20,00^{\mathrm{ns}}$ & 88 \\
\hline 16 & $9351,70 \mathrm{a}$ & $0,62 *$ & $-294367,40^{\mathrm{ns}}$ & 82 & 22,69 & $0,33 *$ & $-18,32^{\mathrm{ns}}$ & 55 \\
\hline 17 & $8294,80 b$ & $-0,16^{*}$ & $-164230,28^{\mathrm{ns}}$ & 2 & 47,08 & $0,84^{*}$ & $27,53^{\mathrm{ns}}$ & 48 \\
\hline 18 & $8564,08 b$ & $0,57^{*}$ & $-227190,10^{\mathrm{ns}}$ & 31 & 31,10 & $1,10^{*}$ & $-10,81^{\mathrm{ns}}$ & 86 \\
\hline 19 & $9101,85 b$ & $0,68^{*}$ & $-243801,17^{\mathrm{ns}}$ & 45 & 34,65 & $1,69^{*}$ & $-19,46^{\mathrm{ns}}$ & 97 \\
\hline 20 & $8895,64 b$ & $1,13^{*}$ & $-203642,42^{\mathrm{ns}}$ & 57 & 42,58 & $1,70^{*}$ & $56,56^{*}$ & 71 \\
\hline 21 & $9538,50 \mathrm{~b}$ & $-1,03^{*}$ & $252399,98^{\mathrm{ns}}$ & 17 & 43,74 & $2,13 *$ & $-2,58^{\mathrm{ns}}$ & 94 \\
\hline 22 & $8148,18 b$ & $2,09^{*}$ & $359596,33^{\mathrm{ns}}$ & 41 & 30,26 & $1,61^{*}$ & $-13,05^{\mathrm{ns}}$ & 94 \\
\hline 23 & $7951,79 b$ & $0,71^{*}$ & $218478,89^{\mathrm{ns}}$ & 9 & 31,59 & $1,19^{*}$ & $-12,87^{\mathrm{ns}}$ & 90 \\
\hline 24 & $8293,04 b$ & $1,28^{*}$ & $-285262,41^{\mathrm{ns}}$ & 91 & 24,89 & $1,34^{*}$ & $272,90 * *$ & 29 \\
\hline 25 & $9185,77 b$ & $0,20^{*}$ & $6740,73^{\mathrm{ns}}$ & 1 & 31,24 & $1,36^{*}$ & $-21,30^{\mathrm{ns}}$ & 98 \\
\hline 26 & $8418,19 b$ & $-0,67^{*}$ & $269642,37^{\mathrm{ns}}$ & 8 & 26,65 & $0,90 *$ & $-14,53^{\mathrm{ns}}$ & 85 \\
\hline 27 & $10459,16 \mathrm{a}$ & $0,31 *$ & $2217519,86^{* *}$ & 1 & 31,41 & $1,33^{*}$ & $-15,78^{\mathrm{ns}}$ & 94 \\
\hline
\end{tabular}

Note. ${ }^{1}$ Averages followed by the same letter do not differ by Scott \& Knott (1974) test ( $\left.\leq 50.05\right)$; ns $=$ non-significant.

(B1) $*{ }^{* *}$ Differs from one, by the $t$ test, at $\mathrm{p} \leq 0.05$ and $\mathrm{p} \leq 0.01$, respectively.

$\left(\mathrm{S}^{2} \mathrm{~d}\right) *, * *$ Differs from zero, by the $\mathrm{F}$ test, at $\mathrm{p} \leq 0.05$ and $\mathrm{p} \leq 0.01$, respectively.

(B1): Regression Coefficient; S² Variance deviation regression; $\mathrm{R}^{2}(\%)$ : Determination Coefficient.

In general, the correlation coefficients were high, except for hybrids $8,14,16,17$ and 24 . This result explains a fitting of the observed data and the regression equation for cob mass. The hybrids with $\mathrm{R}^{2}$ higher than $80 \%$ are considered stable in the environments in which they were evaluated (Cruz et al., 1989). 

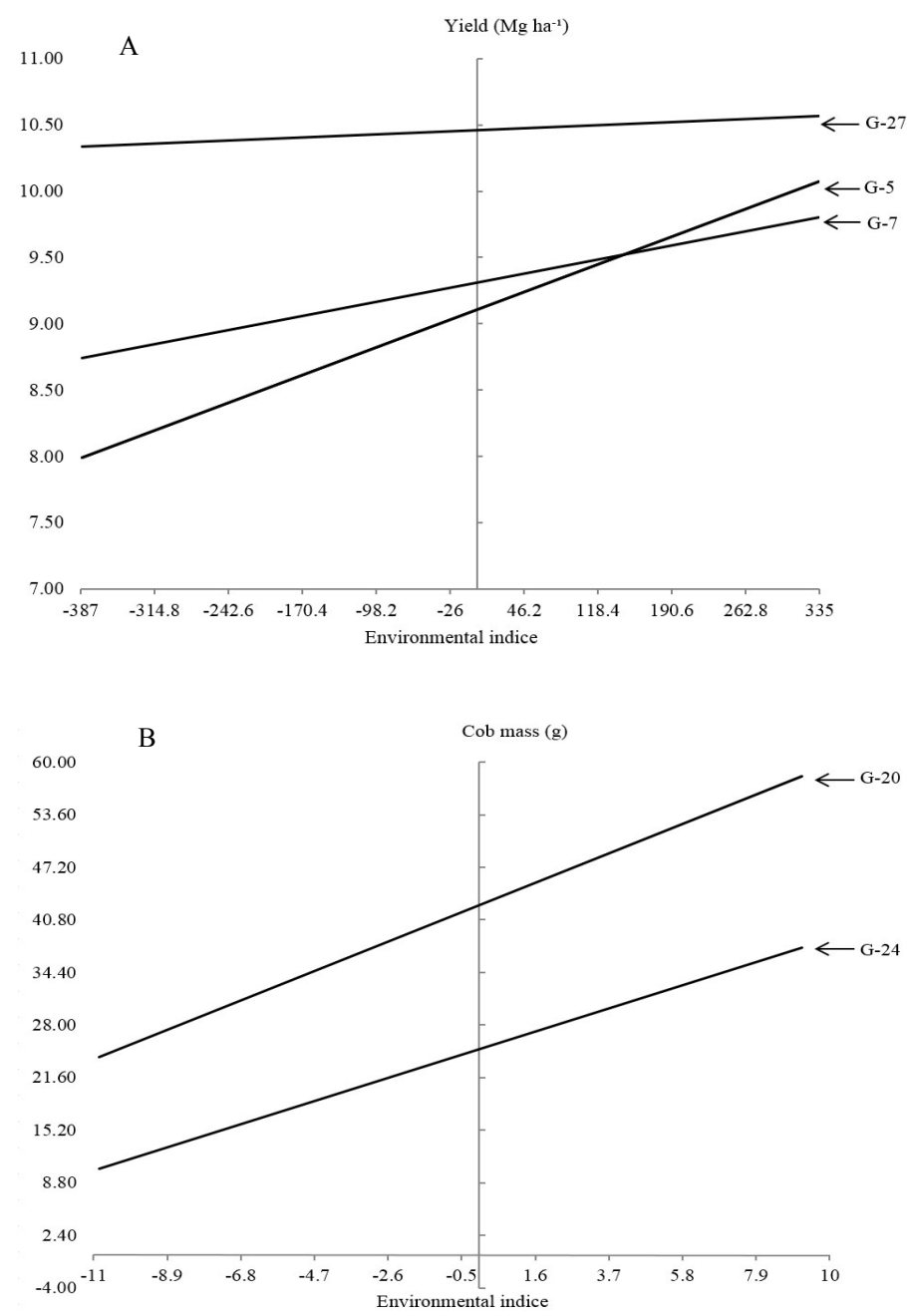

Figure 1. Straight adjusted for grain yield $\left(\mathrm{Mg} \mathrm{ha}^{-1}\right)$ of corn hybrids, due to environmental variations, by the method of Eberhart and Russell (1966). The three hybrids were unpredictable for yield (G5, G7 e G27), (A). Straight adjusted for cob mass character $(\mathrm{g})$ of corn hybrids, due to environmental variations, by the method of Eberhart and Russell (1966). The two hybrids are highly unstable to accumulate cob mass (G-20 e G-24), (B)

\section{Conclusion}

The adaptability and stability performance of hybrids analyzed is different for the set of environments evaluated. The genotypes 20 and 24 are highly unstable for the trait cob mass.

For grain yield, good predictability is found for most hybrids tested. Of the 27 genotypes, three have not shown stability.

\section{Acknowledgements}

To the National Council for Scientific and Technological Development (CNPq) and Coordination for the Improvement of Higher Education Personnel (CAPES) for the support received in this research.

\section{References}

Aguiar, C. G., Schuster, I., Amaral Júnior, A. T., Scapim, C. A., \& Vieira, E. S. N. (2008). Heterotic groups in tropical maize germplasm by test crosses and simple sequence repeat markers. Genetics and Molecular Research, 7(4), 1233-1244. http://dx.doi.org/10.4238/vol7-4gmr495

Allard, R. W. (1960). Principles of plant breeding. New York, NY: John Wiley Sons Inc.

APPS. (n.d.). Evolução da oferta e demanda de sementes de milho no Brasil. Retrieved from http://www.apps.agr.br/upload/de0207200963987700evolucao-oferta-demanda-milho-brasil.pdf

Badu-Apraku, B., Oyekunle, M., Akinwale, R. O., \& Aderounmu, M. (2013). Combining Ability and Genetic 
Diversity of Extra-Early White Maize Inbreds under Stress and Nonstress Environments. Crop Science, 53(1), 9-26. http://dx.doi:10.2135/cropsci2012.06.0381

Badu-Apraku, B., Oyekunle, M., Menkir, A., Obeng-Antwi, K., Yallou, C. G., Usman, I. S., \& Alidu, H. (2013). Comparative Performance of Early-maturing Maize Cultivars Developed in Three Eras under Drought Stress and Well-watered Environments in West Africa. Crop Science, 53(4), 1298-1311. http://dx.doi.org/10.2135/cropsci2012.11.0640

Balestre, M., Von Pinho, R. G., Souza, J. C., \& Oliveira, R. L. (2009). Genotypic stability and adaptability in tropical maize based on AMMI and GGE biplot analysis. Genetics and Molecular Research, 8(4), 1311-1322. http://dx.doi.org/10.4238/vol8-4gmr658

Beiragi, M. A., Khorasani, S. K., Nabavi, M. S., Nikzad, F., \& Zandipour, E. (2011). Study yield stability of commercial corn hybrids (Zea mays L.) evaluated in two planting dates in Iran. African Journal of Agricultural Research, 6(13), 3161-3166. http://dx.doi.org/10.5897/AJAR11.253

Borém, A., \& Miranda, G. V. (2009). Melhoramento de Plantas. Viçosa, MG: UFV.

Cruz, C. D. (2013). GENES - a software package for analysis in experimental statistics and quantitative genetics. Acta Scientiarum. Agronomy, 35(3), 271-276. http://dx.doi.org/10.4025/actasciagron.v35i3.21251

Cruz, C. D., Torres, R. A., \& Vencovsky, R. (1989). An alternative approach to the stability analysis proposed by Silva and Barreto. Revista Brasileira de Genética, 12(2), 567-580.

Eberhart, S. A., \& Russell, W. A. (1966). Stability Parameters for Comparing Varieties. Crop Science, 6(3), 36-40. http://dx.doi.org/10.2135/cropsci1966.0011183X000600010011x

Hallauer, A., Carena, M., \& Miranda Filho, J. (2010). Quantitative genetics in maize breeding. New York, NY: Springer.

Liu, Y., Hou, P., Xie, R., Li, S., Zhang, H., Ming, B., ... Liang, S. (2013). Spatial Adaptabilities of Spring Maize to Variation of Climatic Conditions. Crop Science, 53(4), 1693-1703. http://dx.doi.org/10.2135/cropsci2012.12.0688

Murakami, D. M., Cardoso, A. A., Cruz, C. D., \& Bizão, N. (2004). Considerações sobre duas metodologias de análise de estabilidade e adaptabilidade ${ }^{1}$ Ciência Rural, 34(1), 71-78. http://dx.doi.org/10.1590/S0103-84782004000100011

Naspolini Filho, V. (1975). Variabilidade fenotipica e estabilidade em hibridos simples, hibridos duplos, variedades e compostos de milho (Zea mays L.). Piracicaba, SP: ESALQ.

Niu, X., Xie, R., Liu, X., Zhang, F., Li, S., \& Gao, S. (2013). Maize Yield Gains in Northeast China in the Last Six Decades. Journal of Integrative Agriculture, 12(4), 630-637. http://dx.doi.org/10.1016/S2095-3119(13)60281-6

Pena, G. F., Amaral, A. T. do, Gonçalves, L. S. A., Candido, L. S., Vittorazzi, C., Ribeiro, R. M., \& Freitas Júnior, S. P. (2012). Stability and adaptability of popcorn genotypes in the State of Rio de Janeiro, Brazil. Genetics and Molecular Research, 11(3), 3042-3050. http://dx.doi.org/10.4238/2012.August.31.1

Ramalho, M. A. P., Santos, J. B. dos, Pinto, C. A. B. P., Souza, E. A. de, Gonçalves, F. M. A., \& Souza, J. C. de. (2012). Genética na Agropecuária. Lavras, MG: UFLA.

Schmildt, E. R., Nascimento, A. L., Cruz, C. D., \& Oliveira, J. A. R. (2011). Avaliação de metodologias de adaptabilidade e estabilidade de cultivares milho. Acta Scientiarum. Agronomy, 33(1), 51-58. http://dx.doi.org/10.4025/actasciagron.v33i1.5817

Scott, A. J., \& Knott, M. (1974). A Cluster Analysis Method for Grouping Means in the Analysis of Variance. Biometrics, 30(3), 507-512. http://dx.doi.org/10.2307/2529204

Yan, W., Hunt, L. A., Sheng, Q., \& Szlavnics, Z. (2000). Cultivar Evaluation and Mega Environment Investigation Based on the GGE Biplot. Crop Science, 40(3), 597-605. http://dx.doi.org/10.2135/cropsci2000.403597x 


\section{Copyrights}

Copyright for this article is retained by the author(s), with first publication rights granted to the journal.

This is an open-access article distributed under the terms and conditions of the Creative Commons Attribution license (http://creativecommons.org/licenses/by/3.0/). 